\title{
Green Infrastructure retrofit -a Sustainable Strategy for Indian city
}

\author{
Ar. Arhsia Khajooria Hazarika ${ }^{1}$, Ar. Anoop Kumar Sharma ${ }^{2}$
}

\begin{abstract}
The Urbanization has become an inseparable part of the global scenario. Thus, to tackle the problems related to urbanization, Green Infrastructure has become established as the central approach to landscape planning and grown in prominence since it was first discussed in the late 1990's and is known and implemented in the UK, Western Europe and North America. This concept has been related with positive result as case studies of Europe and USA are success stories and it has developed as an approach to landscape planning that addresses the fragmented and fractured approach associated with urbanization. Green infrastructure so far has not been holistically tried as a part of retrofitting in Indian cities. Retrofit approach will address issues with least possible disturbance to existing urban scene .This research proposal intends to study the current urban issues with unplanned sprawling and environmental repercussions and propose green infrastructure for the city of Jammu the winter capital of the state of Jammu and Kashmir, India as the case study. Green Infrastructure shall be as typically incorporated into the progression for urban greening and pursue region based approach to develop urban planning and sustainability for the city.
\end{abstract}

Keywords-Green infrastructure, environment, retrofit, urbanization.

\section{INTRODUCTION}

The city of Jammu is the winter capital of the state of Jammu and Kashmir. Jammu city (32044'N and 74055'E) is known as the city of temples and has various sites of historical importance with sub hilly topography .It is vital and of great importance due to its location, cultural identity, unique traditional architecture and connectivity with the rest of the nation being the sole road and rail link. It is surrounded by areas of tourism and pilgrim attraction and thus a great revenue generator for the state. This district has an area of 2,336 sq km and had a population of 15.27 lakh as per census 2011 . This city has witnessed unprecedented growth since 1990, owing to the mass exodus of the Kashmiri pundits from the Kashmir valley. A sudden marked increase in population has led to crumbling of already insufficient infrastructure and related urban vices. This city started as a settlement along the river Tawi and has grown in a linear fashion over the years in an unplanned and erratic manner. City is has a hilly terrain, the old city and fortress is located on a hillock on the banks of the Tawi river. The old city is confined to the right bank of the River Tawi a tributary of

Arshia Khajooria Hazarika, College / University: Asso. Professor, Nitte School of Architecture, Bangalore, Country:India

Anoop Kumar Sharma, College / University: Asst. Professor in Architecture, SMVD University, Katra (Jammu and Kashmir), Country:India
River Chenab whereas the later expansions of the city have taken place on the left bank with some colonies on the right bank also. The residential density varies from of old city works out as 587 to 357 persons per hectare. Biodiversity has depleted with urbanization and human insensitivity. Tawi has added to safety concerns in the recent past, September 2014 due unprecedented floods have added to safety concerns in the recent past. The proposal shall conclude with a retrofitting proposal of green infrastructure for this city with aim to mitigate loss of biodiversity, climate change, water resource exhaustion with water management, reduction food production.

The climate of Jammu varies between tropical and Monsoon type. Winter season lasts for three months i.e. December to February with a mean monthly temperature between 13.5 o to $20.0 \mathrm{o} C$ and a rainfall of about $150 \mathrm{~mm}$. The summer season sets in from March when the temperature begins to rise and continues to rise up to June when the mercury reaches above 40 o C. South east monsoon normally arrives in Jammu by the first week of July and ends in mid September. In October and November, the weather is generally dry. Shown as the cold and cloudy in climatic zone map of India, Jammu has composite climate and is similar to Delhi. The highest temperature ever recorded in last few years is $47^{\circ} \mathrm{C}$ in the month of May and the lowest ever recorded is $1.7^{\circ} \mathrm{C}$ in the Month of January

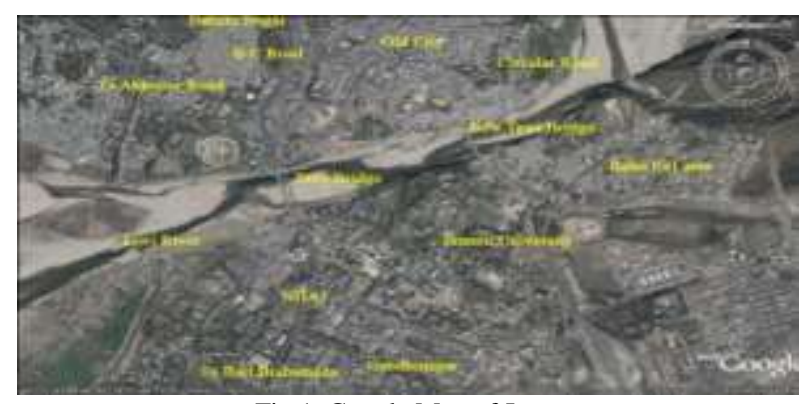

Fig 1. Google Map of Jammu 


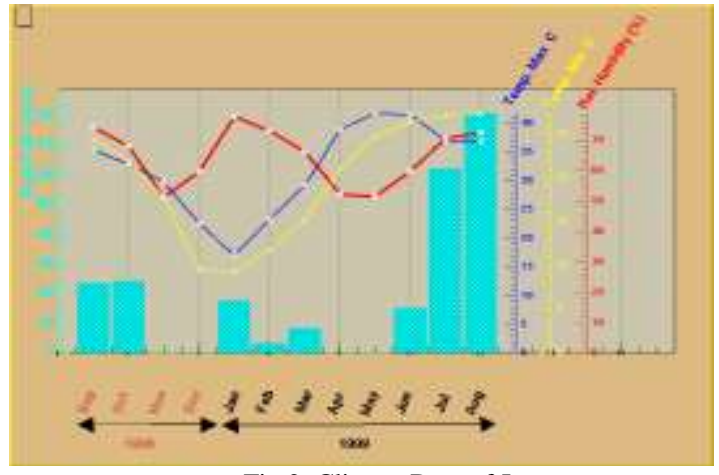

Fig 2. Climate Data of Jammu

\section{GREEN INFRASTRUCTURE}

The infrastructure such as roads, sewers and utility lines is grey infrastructure \& hospitals, schools and prisons are social infrastructure. A new type of infrastructure, which is known as green infrastructure (GI) is accepted as an urban solution. GI definitions vary from expert to expert, but most accepted is the following, "GI is a network of multi-functional open and green space in and around towns and cities the gardens, trees, rivers, woodland, parkland, nature reserves and urban wild space, and the access to and through them, which support wildlife and biodiversity, provide recreation, access and leisure opportunities and create a sense of place" (MacDonald et al., 2005 and Kevin Sullivan, 2010). GI facilitates achieve sustainability by yielding flexibility to goals with an assortment of assenting results along with climate modification. Remuneration include enhanced management of storm-water runoff, lowered incidents of combined storm and sewer overflows (CSOs), water capture accommodation of natural hazards (e.g., relocating out of floodplains), and reduced ambient temperatures and urban heat island (UHI) effects. The U.S. Environmental Protection Agency (EPA) has also identified green infrastructure as a contributor to improved human health and air quality, lower energy demand, reduced capital cost savings, increased carbon storage, additional wildlife habitat and recreational space, and even higher land-values of up to $30 \%$. It has two basic components:

When you submit your final version, after your paper has been accepted, prepare it in two-column format, including figures and tables.

\section{A. Green infrastructure Resources}

Resources of green infrastructure are parks, lakes and woodlands, urban intercession such as green roofs and street trees. They are particular sites at the neighboring level or at landscape scale within and between rural and urban areas such as wetlands and mountain ranges.

\section{B. Green infrastructure Utility}

GI utility comes from job that resources perform if planned, executed and managed in a way that is amenable and prerequisite for natural features and ecosystem. They have apparent primary functions, with multi functionality such as the street trees have aesthetic quality for urban area, but also reduce air pollution, provide shade, reduce urban heat island effects, mitigate wind chill and turbulence and increase biodiversity.
Green infrastructure encompasses a wide variety of natural and restored native ecosystems, landscape features that make up a system of "Hubs" like the community parks and natural areas, regional parks and natural reserves and "Links," like conservation corridors - greenways, greenbelts and eco-belts.

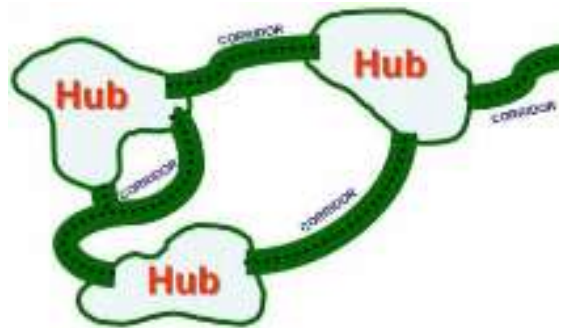

Fig 3. Green Infrastructure Network, Adapted from the Conservation Fund, 2007

\section{URBAN ISSUES FOR DELIBERATION FOR GREEN INFRASTRUCTURE RETROFITTING}

\section{A. Urbanization and sprawl}

The old city already has high density with narrow lanes and ever intensifying commercial activities along with traffic congestion, water shortage, improper waste management and environmental degradation. Population growth and development has led to the horizontal expansion of city especially towards the south along the NH 1A road with rapid urbanization engulfing many villages under the urban sprawl with reduction agricultural land and production of food grains

\section{B. Environmental pollution}

Jammu city is said to be second only after Tokyo in the list of cities with maximum density of automobile traffic across the world thus making traffic as major source of air pollution. Long period of power cut especially in summers force people to use kerosene and diesel generators further contributing to pollution. Emissions of greenhouse gases like carbon dioxide, hydrocarbons, carbon monoxide are leading to increase in city temperature. Health hazard like asthma in small children is at an increase. The major cause of noise pollution is traffic, minibuses with blaring music with domestic vehicles joining the row and the generators for frequent, long power cuts.

\section{Climate change and water shortage pollution}

The River Tawi is main source of water supply along with tube wells harnessing ground water. The increasing population density, reducing greens, rapid deforestation and unrestrained industrial growth has led to ecological imbalance and pollution. All this has resulted in climatic change with less rains, hotter summers, along winters becoming more severe. Less water in the Tawi river basin along sometimes erratic rainfall as witnessed in 2014 September led to unprecedented floods. During September 2014 flash floods, several residential colonies constructed illegally along the river bank were damaged following which the administration had promised to stop any such activities in the future

\section{Lungs of the city}

The green patches around winter capital are the lungs of the city. As seen in the landuse map only 2 percent reserved forest with very little dispersed green in Jammu city, rest is all grey 
.They have been shrinking at fast pace due to the demand of land for residential, commercial and industrial purposes. A large number of green trees have come under the axe for widening Jammu-Pathankot bypass road and under four-lane project of NHAI right from Pull Doda to Bhaderwah. The illegal felling of tress from forest reserve area for fire wood and construction activities mostly on encroached land has caused loss of biodiversity. The personal gardens with green cover giving way to hard surface thus causing water runoff and increase in temperature and level of groundwater depletion.

\section{E. Urban heat island effect}

This urban area is significantly warmer than its surroundings. Concrete surfaces radiate heat forming an area or an island of high temperature. The temperature has been on the rise since past few decades with summer temperature soaring up to $48^{\circ} \mathrm{C}$, leading to deaths due to heat waves.

\section{GREEN INFRASTRUCTURE PROPOSAL FOR JAMMU CITY}

For the purpose of retrofitting firstly step is assessing existing GI. Jammu has a high density built up area as shown by the land use plan and green pockets are limited .Mostly residential about 70 percent with high and low density, mostly with flat roofs. River banks and roads lack green belts and city had a fragmented landscape. The circulation is about 15 percent which would act as link eco belt and green belts to the hubs. The Tawi river flows through steep hills on either side excepting the lower reach for about $35 \mathrm{~km}$ (22 mi)and is about $300 \mathrm{~m}(980 \mathrm{ft})$ wide at the bridge in Jammu city. Proposal for urban forestry and wet lands along the length of the river is proposed as a green infrastructure measure. The proposal thus has been worked out for connecting landscape with eco roof, greening balconies, further linking with green community parks and roadside ecological belts to mitigate urban heats island effect, energy conservation, aesthetics, storm water management.

\section{A. Eco-roof}

GI retrofit is possible in Jammu with large built up area both residential and commercial by incorporating Eco roofs. Eco roofs can be either Green roofs or white roofs or blue roofs depending on the need for function. These eco-roofs have distinct benefits in comparison to usual "black roofs" just for shelter . The black roofs of the building can be converted into any of the Eco-roofs to achieve additional sustainability, along with water conservation and management, cooling, , energy conservation and habitat local birds and animals , and carbon sink along with aesthetic appeal

\section{B. Green roof}

As the per the nomenclature they support vegetation cover partly or completely that of the local species of plants grown on 3-15 inches of a combination of soil, sand, or gravel on a waterproof membrane. Vegetation may be in modular trays or on soil spread across the roof. Green roofs have to support the weight of the soil cover for plantation and that of plants and water so the roof should be structurally designed and reinforced for such requirement. In case of already constructed buildings this roof can be installed if they roof has been additionally reinforced for other purposes or can reinforced for additional weight with extra cost. Green roofs have extra function of protection of roofing material from wind damage, UV rays, and extreme temperature impacts, thus increasing roof life-spans of roofs reducing lifecycle cost. As per CCAP final report of Feburary 2011 on GI, these roofs can reduce annual storm water run-off by $50-60 \%$ on average, including peak runoff. A sampling of studies shows annual energy savings from green roofs at $15-45 \%$ of, mainly from lower cooling costs. The overall financial benefits ranging from extended roof-life, insulating value, reduced urban heat island effects, local and regional water quality improvements, fewer combined sewer overflows (CSOs), urban biodiversity, noise dampening, increases in aesthetic and property values and nominal carbon capture.

\section{White roof-urban heat management}

Urban heat island effect (UHI) is a result of built environment with impervious surfaces like roofs and pavement to absorb heat making the city hotter than its hinterlands by 2 to $5.5^{\circ} \mathrm{C}$ on hot days. White are cool roofs mostly flat roof are painted with white either light or reflective material making it resilient along with decreasing ambient temperatures. The old building $\mathrm{s}$ of the old city is proposed be retrofitted with white roof without need for additional reinforcements. The white roofs not only lower ambient temperature but also lessen the UHI effect .As per EPA Heat Islands Compendium (Oct. 2008) the white vinyl roofs are the most reflective common material used, reflecting $80 \%$ of the sun's rays compared to only $6 \%$ reflection on a conventional black roof and avoiding $70 \%$ of the heat absorption experienced on black roofs. A 2009 study by the Lawrence Berkeley National Laboratory's (LBNL) Heat Island Group found that retrofitting $80 \%$ of air-conditioned buildings in the United States with white roofs would save $\$ 735$ million annually in reduced energy bills while achieving an emissions reduction equivalent to removing 1.2 million cars from the road. Another study by LBNL in 2010 used global climate models found that increasing the reflectivity of surfaces in urban areas with a population of over one million would reduce global heating by $0.4^{\circ} \mathrm{C}$ on average. This in turn would offset the heating effect of 1.2 gigatons of $\mathrm{CO} 2$ emissions annually, the equivalent of taking 300 million cars off the road for 20 years.

\section{Blue roof-water management}

Blue roof practices address the growing need for water management and storm-water runoff. The blue roof use technologies with downspout valves, gutter storage systems and cisterns and can be installed on a roof with slope less than 2 per cent. A waterproofing membrane has to be installed as part of the roofing system for blue roof and preferably water to be retained not more than2' -4 ' depth and not more than 24 hours as per NYC codes. Water in these roofs can be temporarily harvested for non-potable uses on-site and used for landscape irrigation, direct groundwater recharge or discharged in sewer systems at a reduced flow rate from storms. As per LEED Standards the blue roofs can earn 1 LEED credit and water storage mechanisms for reuse earning 3-4 LEED credits .As comparison with green roofs these roofs can be retrofitted on standard black roofs without any additional structural support system with no discharge the nutrients and chemicals. Studies 
show a typical blue roof with storage capability can store about $50 \%$ of the water that falls on it annually. Thus reducing the need for water treatment there is saving in energy and carbon emissions as well. An alternating blue roof and green roof system on the same roof can be an effective eco roof is proposed for buildings built after 1970s.

\section{E. Green streets and pavements}

Streets usually surfaced in hard, dark materials many a times devoid of trees leading to higher ambient temperatures, thus increasing energy demand cooling and surface water runoff. Green lanes can achieve storm water management, heat cutback and energy management objectives. In addition, green and permeable- lanes streets and pavements earn LEED credits for urban sustainability. Permeable paving material are useful in storm-water water quality preservation, reduced water reduces municipal pumping demand and electricity costs, meeting both mitigation and adaptation objectives. As per Rooftops to Rivers (2006) NRDC Permeable pavement in a typical alley can infiltrate 3 inches of rainwater from a 1-hour storm with an infrastructure life expectancy of 30 to 35 years. Cool lanes, streets and pavements are pavement technology such as Resin based pavements, tend to store less heat and may have lower surface temperatures compared with conventional products. Researchers at LBNL, however, have estimated that every 10 percent increase in solar reflectance could decrease surface temperatures by $7^{\circ} \mathrm{F}\left(4^{\circ} \mathrm{C}\right)$.

\section{F. Urban forestry and green belts}

Trees Plantation in urban situation is considered a prototypical GI practice known as urban forestry. Trees contribute storm-water runoff flow which prevent flooding and manage water quality, absorb air pollutants, act as wind-breaks to protect buildings and mitigate UHI through shading and evaporation. Hence lower demand for electricity and directly impound carbon. Trees are habitat for regional species thus maintain natural ecosystem balances. Dead trees even can be recycled into compost, manure etc. For Urban forestry to be implemented trees will be planted in public spaces like parks, along streets and lanes, as buffer in open spaces that along river, around buildings, or in vacant areas. Thus under retrofit proposal the green-belts around cities can be extended around the lanes, street to form linkages .An urban forest belt along the River Tawi will along with environmental benefits regulate development and protect urban watersheds so that drinking water supply and quality is protected. As per EPA Heat Islands Compendium (October 2008): The estimated effect of new shade trees planted around houses resulted in annual cooling energy savings of $1 \%$ per tree while annual heating energy use decreased by almost $2 \%$ per tree. During the summer, with trees in full leaf, evergreens and conifers in Sacramento, CA were found to intercept over 35\% of the rainfall that hit them during smaller rainfall events. Trees reduce runoff and erosion from storms by about $7 \%$ and reduce the need for erosion control.

\section{G. Wetlands}

As early as 1960s, urban planners began to recognize that wetlands buffer regional infrastructure and housing against flooding. AS per Columbia University Green Roof Project
Submission Date (July 26, 2007)in May of 2006, the community of Lawrence, Massachusetts received 8.7 inches of rain over several days, resulting in an estimated $\$ 19$ million in flood damages. At the same time, communities along the Charles River, including Boston and Cambridge, received 9 inches and suffered almost no flood damage. The protected wetlands provide a wide range of other water quality, recreational and economic benefits as well. During the flash floods in Jammu in 2014 , one of the worst floods in decades, environmentalists have blamed intrusion of the wetlands like rivers, streams, riverside wetlands, man-made ponds and tanks as the main reason for this devastation .Thus wetland systems are most effective cost effective alternatives in buffering communities against flooding.

\section{H. Green walls}

Green Wall with another name Vertical Garden, used to refer to all form of vegetated wall surfaces (Green roof organization 2008). Green walls add to aesthetics and can be a major enhancing element for urban design. Green walls can absorb heated gas in the air, lower both indoor and outdoor temperature, providing a healthier indoor air quality as well as a more beautiful space (Yeh 2012). They holds or slows rainwater runoff, providing food and shelter for wildlife (Thompson and Sorvig 2000).The communities can retrofit there buildings selectively with green wall in places like a southwest facing wall of buildings ,boundary wall Jammu, balconies and along the window sills etc to reap the benefits of the same.

\section{RECOMMENDATIONS AND CONCLUSIONS}

G I approach should be an essential components of all new and redevelopment policies, with focus on retrofitting existing urban environment with green infrastructure as part communities and stakeholders attempt to counter urban challenges. This concept is not widely recognized in many developing nations which is a matter of concern as GI mitigates to a vast range of challenges. The benefits attributed to GI therefore need to take into consideration how people, policy and place are influenced by the three main components of sustainable development: social, ecological and political equity (Mell, 2010).The multi functionality of GI in urban areas as contributing to creating healthy and comfortable places where people or visitors want to live, recreate and work is an established fact supported by various case studies. G I retrofitting with tactically designed and managed system of green spaces is imperative to the sustainability of any urban area such as Jammu city. The concept requires great deliberation to plan, develop and manage the existing GI resources and possible retrofit the cities with same. For the purpose of retrofitting cities with GI, a proper planning, policy and promotion for GI development and retrofit to be followed. The stakeholders can be inspired case studies of G I from the rest of the world. The planning and implementation can be expedited by ensuring subsidies where warranted in 
Jammu thus GI can be achieved in this city with minimal cost and land acquisition and creating incentives in policy .So while selecting a retrofit policy option, the first step would be to understand the most significant barriers for implementation and overcoming them with setting of target with incentive program. Incentives should be in form of policies economic advantage such as subsidies and tax reductions in form of rebate for reducing the economic burden of infrastructure by incorporated GI programs. The active involvement of stakeholders must be at local, regional and national planning policy particularly, in developed countries. Sustainable communities are places that balance their economic assets, natural resources, and social priorities so that residents' diverse needs can be met now and in the future (EPA, 2014). The reductions in tax revenue can be justified by the decreased demand on municipal services provided by green infrastructure. As segment of the smart growth for more sustainable living and climate change adaptation, the addition to GI, is recognized as a must for it has a number of multi-functional benefit to the community Moreover, planning and decision making for vibrant and environmentally sustainable communities requires a systems perspective that integrates green and grey infrastructure (Kimmel et al., 2013).

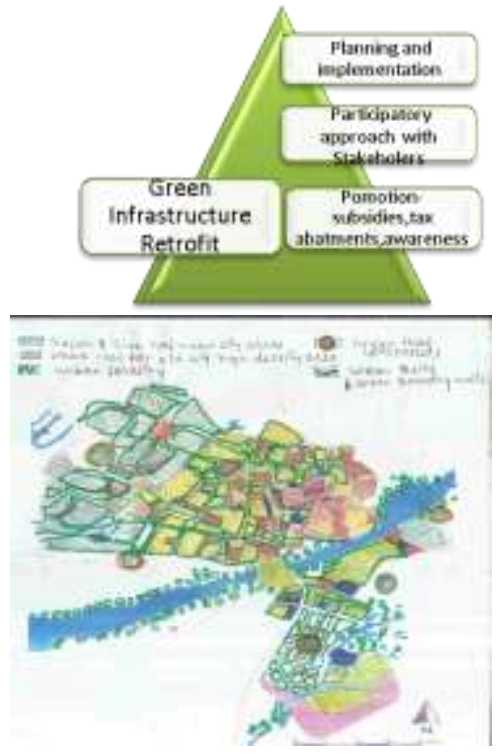

Fig 4. . Proposal of implementing green infrastructure in Jammu city (source: :author)

Incorporation of Green infrastructure to the spatial structure shall transmit benefits from nature to people, augment nature's ability to transmit multiple precious ecosystem services, such as

- Improved quality of life and well-being by providing quality environment in which to live and work.

- Improve biodiversity, like by reconnecting isolated natural areas and increasing the mobility and survival of wildlife across the wider landscape.
- Mitigate impact of climate change and other environmental disasters, for instance by alleviating floods, storing carbon or preventing soil erosion.

- Foster smarter, more integrated approach to development which ensures space utilization is efficient and coherent.

Thus enhancing urbanization and development with green infrastructure for reaping benefits of globalization and striding towards future sustainability is the objective of the study.

\section{REFERENCES}

[1] Ar.ArshiaKhajooriaHazarika" Sustainable Growth Of Existing Cities -A Myth Or Reality". International Conference on Urbanism \& Green Architecture at NIT Hamirpur, H.P 30th -31st Oct. 2010

[2] Ar.Arshia Khajooria Hazarika,"Bio-climatic High-rise for Sustainable Housing"Desicripto -.An international Journal of Design(ISSNNo. 22494480)Vol.1, 2011 ,Pg no .106

[3] Kimmel, Courtney, David Robertson, R. Bruce Hull, Michael Mortimer, and Kris Wernstedt (2013)" Greening the Grey: An Institutional Analysis of Green Infrastructure for Sustainable Development in the US."Center for Leadership in Global Sustainability, Virginia Tech, 2013D.E. Tallman, G.G. Wallace, Synth. Met. 90 (1997) 13.

[4] Jammu Development Authority, Master Plan for Jammu : 2021

[5] The Burning Paradise, 13, October, 2009, Escalating air, noise pollution causing environmental degradation in $\mathrm{J} \& \mathrm{~K}$.

[6] Benedict, MA \& McMahon, ED (2006) Green Infrastructure: linking landscapes and communities.Island Press, WashingtonBenedict,

[7] Benedict, MA \& McMahon, ED (2002) "Green Infrastructure: Smart Conservation for the 21st Century."Renewable Resources Journal. Autumn Edition. Pg. 12-17

[8] MikiasBiazenMolla“,Green Infrastructure Planning and Development for Sustainable Urban Development: A Literature Review”, International Journal of Environmental Sciences Vol. 4 No. 2. 2015. Pp. 59-67k

[9] Kevin Sullivan(2010). Green Infrastructure Planning Guidelines for Coastal Georgia, http://www.coastalgadnr.org/cm/green/guide

[10] McDonald, L., W. Allen, M. Benedict, \& K. O'Connor (2005). Green Infrastructure Plan Evaluation Frameworks, Journal of

ConservationPlanning1(1):12-4..PlaNYStormwater(2008)http://s-media .nyc.gov/agencies/planyc2030/pdf/nyc_sustainable_stormwater_manage ment_plan_final.pdf

[11] Green Roof: Final Presentation, Gateway Team, Columbia University Green Roof Project Submission Date (July 26,2007)http://community.seas.columbia.edu/cslp/reports/summer07/gre enroofGreen_roof_final_pdr.pd<http://www.wbdg.org/resources/greenro ofs.php

[12] National Institute of Building Sciences website, Extensive Green Roof Definition 20Green Roof: Final Presentation, Gateway Team, Columbia University Green Roof Project Submission Date (July 26,2007) $<$ http://community.seas.columbia.edu/cslp/reports/summer07/greenroof Green_roof_final_pdr.pd<http://www.wbdg.org/resources/greenroofs.ph

[13] EPA Heat Islands Compendium (October 2008: Cool Roofs) https://www.epa.gov/heat-islands/heat-island-compendium

[14] http://iopscience.iop.org/article/10.1088/1748-9326/8/1/015023/meta

[15] Rooftops to Rivers (2006) NRDC 52"Greening Gets Down and Dirty," Timothy B. Wheeler, Baltimore Sun (August 20, 2010)http://articles.baltimoresun.com/2010-08-20/features/bs-gr-subsoili ng-20100820_1_polluted-runoff-storm-drainsstorm-water-pollution

[16] Ed MacMullan, Presentation: "Assessing Low Impact Developments Using a Benefit-Cost Approach," ECONorthwest, 2nd Annual Low Impact Development Conference (March 12-14, 2007) http://www.econw.com/reports/Low-Impact-Development_Benefit-Cost. pdf

[17] http://www.downtoearth.org.in/news/urban-floods-lessons-from-jammukashmir-46274

[18] Fact Sheet \#4 website: Control Stormwater Runoff with Trees, Watershed Forestry Resource Guide, A Partnership of the Center For Watershed Protection and US Forest Service - Northeastern Area State \& Private Forestry http://www.forestsforwatersheds.org/reduce-stormwater/

[19] http://www.tribuneindia.com/news/jammu-kashmir/community/encroac hers-out-to-grab-tawi-river-banks-again/182347.html

[20] http://www.mapsofindia.com/maps/jammuandkashmir/jammu-city-map. html. 
[21] http://www.crdeep.com/wp-content/uploads/2015/04/Vol-4-2-4-IJES.pdf

[22] http://cdn.intechopen.com/pdfs/45441/InTech-Vertical_gardens.pdf

[23] http://www.mapsofindia.com/maps/jammuandkashmir/jammu-citymap.h $\mathrm{tml}$

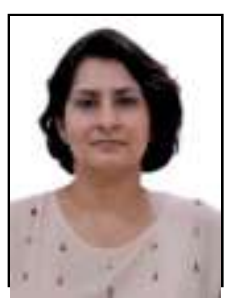

First Author Ar.Arshia Khajooria Hazarika is an Associate Professor at NITTE School of Architecture IN Bangalore, Karnataka-India. She was born on $28^{\text {th }}$ September 1971 at Srinagar,-India.She passed her Architecture Degree with Honours in First class ,FROM Sir.J.J.College of Architecture ,Mumbai,Maharastra -India in 1995.She is currently involved in research on smart resolutions in tier II and Tier III cities. Her research publications are mostly on vernacular techniques and sustainability.

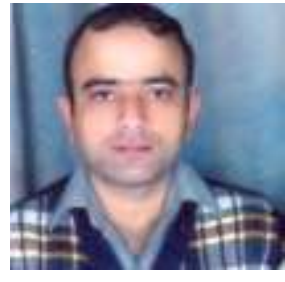

Second Author: Ar. Anoop Sharma is Serving as Assistant Prof. in Department of Architecture and Landscape Design, Shri Mata Vaishno Devi University, Katra-India. He did his Graduation as Gold- Medalist in 2008 \& PG (Ist Class) in 2012. Presently, he is actively engaged in Research pertaining to Contemporary approaches in Urban Planning, Architecture Style of 2nd Tier Indian Cities 